providing assistance to national authorities in defining specific policy-options and suitable response measures.

The development of climate scenarios for the Mediterranean region has been initiated. They are planned to be completed in 1990, and to be used in connection with the revision of the Mediterranean regional study.

On a global scale, a review of the interaction of the oceans with 'greenhouse' gases and atmospheric aerosols has been published, and a bibliography on the effects of climate change and related topics has been prepared by the Mediterranean Task Team.

StJePAN KeCKes, Director
Oceans and Coastal Areas Programme
Activity Centre
United Nations Environment Programme
P.O. Box 30552
Nairobi, Kenya.

\title{
Global Education Associates
}

This body, commonly referred to by its acronym of GEA, was founded in 1973 as a response to the realization that we live in a new era - a historic transition in which the futures of all individuals, groups, and nations, are irreversibly interconnected.

GEA is a network of individual and institutional associates in more than 80 countries, seeking to empower people to become active participants in shaping a more just, peaceful, and sustainable, world future. The Associates are united in a common world-view that recognizes the oneness and sacredness of the whole earth community, including the Planet Earth itself.

The historical roots of Global Education Associates are in 20 years of development work by its founders, the undersigned, in local self-help community development programmes in Latin America and East Africa. This experience bore witness that, in today's interdependent world, local and global concerns are profoundly intertwined. GEA was founded with awareness that non-governmental organizations-secular and religious-around the world must join hands as bold, creative actors in this pivotal transition period in human history.

GEA's associates work together to catalyse a transnational multi-issue movement for policies and structures capable of responding to the crises and opportunities of today's interdependent world. Special emphasis is placed on reconceptualizing security and sovereignty within the context of ecological and economic interdependence. Towards this end they conduct research; organize public and leadership seminars; produce publications and audiovisuals; sponsor and conduct public education programmes; offer consulting services; and facilitate networking at local, national, and international, levels. Their programs and publications are designed to advance cooperative win-win solutions to today's critical global-scale problems.

The appended 'Highlights of 16 Years: An Overview Report' lists some of GEA's accomplishments and describes some of its projects and programmes.

$$
\begin{aligned}
& \text { Gerald F. Mische, President } \\
& \quad \& \\
& \text { PATRICIA MiSCHE } \\
& \text { Global Education Associates } \\
& \text { Suite } 456 \\
& 475 \text { Riverside Drive } \\
& \text { New York } \\
& \text { NY 10115, USA. }
\end{aligned}
$$

\section{HighlightS OF I6 YeARS: \\ AN OVERVIEW REPORT \\ Global Education Associates}

GEA is an international network of men and women in more than 80 countries who conduct research, policydevelopment seminars, and educational programmes, aimed at advancing world peace and security, cooperative economic development, human rights, and ecological sustainability.

1) GEA is a growing global network of associates in over 80 countries.

2) More than 2,500 workshops, institutes, and symposia, have been conducted by GEA staff and associates around the world.

3) The International Center for World Order Alternatives has been established in New York City. The first group of international scholars is scheduled for the 1989-90 programme year.

4) The Asian Institute for a New World Order, opened in Manila, Philippines, in 1987, links individuals, institutions, and organizations, in Asia in research and educational programmes focusing on Asian perspectives for world order alternatives. GEA associates are working to develop parallel regional institutes in Africa, Europe, and Latin and North America.

5) Partners for World Order Alternatives : Building on its experience of multi-issue and movement-building and global networking, GEA initiated a collaborative partnership that links a growing number of organizations and institutions around the world in a process of reconceptualizing security and sovereignty in a context of global interdependence.

6) Project Global $\mathbf{2 0 0 0}$ is the central programme expression of the above partnership. It is designed to produce global-frame documents in 50 countries that will examine the interrelated issue areas of global security. environment, debt and development, health, landagriculture, human rights, and global spirituality, in the context of global interdependence. Its research and outreach programmes focus on policy and systems development that should be achievable during the 1990s.

7) More than $\mathbf{5 0}$ religious networks, most of which are transnational, have become formal partners with GEA, which has conducted workshops for their leadership and general membership, and facilitated their involvement in concrete projects around the world.

8) A 17-parts' television series for CBS, based on the Misches' book, Toward a Human World Order, was developed by GEA staff and associates.

9) Accredited graduate-level institutes on global issues and interdependence have been conducted by GEA staff and associates at more than 25 universities around the world.

10) The Earth Covenant: A Citizens' Treaty for Common Ecological Security: A Soviet-American initiative to establish and institutionalize the right to a healthful environment and to develop a world-wide consensus on principles, policies, and systems, for ecological security.

11) Publications Breakthrough - a quarterly publication The Whole Earth Papers - a series of monographs International Perspectives in Public Health-a scientific journal. 